\title{
Organic and inorganic human-induced contamination of Posidonia oceanica meadows
}

\author{
Gérard Pergent $^{a}$, Céline Labbe ${ }^{a,{ }^{*}}$, Céline Lafabrie ${ }^{a, b}$, Roger Kantin $^{b}$, Christine Pergent-Martini $^{a}$
}

\footnotetext{
a UMR CNRS 6134 - EQEL, University of Corsica, Faculty of Sciences, BP 52, 20250 Corte, France

b IFREMER, Mediterranean Center, BP 330, Zone portuaire de Brégaillon, 83507 La Seyne-sur-Mer Cedex, France
}

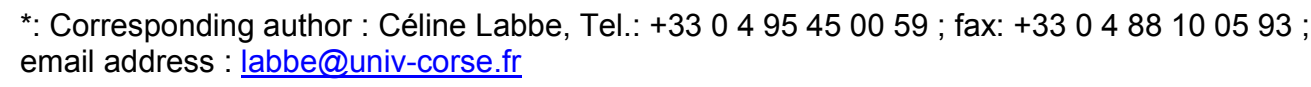

\begin{abstract}
:
In coastal environments, plants are used for phytoremediation of contamination. Organic and inorganic contaminants may be due to natural and/or anthropogenic sources. The aim of this study is to compare inorganic (trace metal) and organic (PAH) contamination in Posidonia oceanica and to analyse the relationship between these types of pollutants indeed very few studies have been interested in their correlations and common sources. $P$. oceanica leaves were collected in two sites exhibiting different levels of human-induced pressure. Higher values were recorded in the more polluted site (Toulon) for trace metals (Ag, $\mathrm{Hg}, \mathrm{Pb}$ ) as well as for PAHs (Medium Molecular Weight and High Molecular Weight) due to the presence of the city and/or harbour in proximity. For the first time in a coastal environment, correlations were observed between metals and PAHs.
\end{abstract}

Keywords : Trace metals ; Polycyclic aromatic hydrocarbons ; Contamination ; Seagrass ; Posidonia oceanica; Mediterranean 


\section{Introduction}

The Mediterranean sea, characterised by a rich biodiversity $(7 \%$ of world marine species in $0.8 \%$ of the ocean surface), is threatened (Benoit \& Comeau, 2005; EEA, 2006). Indeed, its coastal area is characterised high anthropogenic activities such as tourism, transport and industrial activities; responsible of chemical contaminations such as trace metals and hydrocarbons (Benoit \& Comeau, 2005). Some of these substances present accumulative properties, as well as in some cases mutagenic and/or carcinogenic properties (Belpomme et al., 2007).

Trace metals are introduced in costal environments through run-off and atmospheric deposition (Benoit \& Comeau, 2005). They may be present as natural compounds but they have also been linked to domestic, agricultural and industrial activities (Murray et al., 2004). Mercury ( $\mathrm{Hg})$ and lead $(\mathrm{Pb})$ are listed as priority substances of the European Union Water Framework Directive (WFD) and as priority pollutant by several international organizations (e.g. US Environmental Protection Agency, Barcelona Convention). Silver (Ag), very toxic compound, is produced by metallurgy, industries and introduced in sea by run-off and sewer (Kantin \& Pergent, 2007).

Among organic contaminants, hydrocarbons produced by terrestrial sources are more represented than those produced accidentally or operationally (Benoit \& Comeau, 2005; NRC, 2003). For instance, Polycyclic Aromatic Hydrocarbons (PAHs) are naturally produced (e.g. natural seep) but contamination is mainly of anthropogenic origin (e.g. extraction, transportation and consumption of petroleum; NRC, 2003).

There is currently a great interest in the use of living organisms as pollution biomonitors in aquatic ecosystems (Goldberg, 1986; Pergent-Martini \& Pergent, 2000; Usero et al., 2005). Most of these studies are based on the use of caged mussels, Mytilus galloprovincialis (Andral et al., 2004; Baumard et al., 1998a; Stella et al., 2002). However, in coastal environments seagrass are naturally widespread (Short et al., 2001) and have already been adopted for a number of monitoring purposes (trace metals: Lafabrie et al., 2007; radionuclide: Baysal \& Tuncer, 1994; Calmet et al., 1991; Warnau et al., 1996; PCB: Doust et al., 1994; Haynes et al., 2000). Plants are also used for phytoremediation (Huesemann et al., 2009; Lin \& Mendelssohn, 2009; White et al., 2002). The Mediterranean endemic seagrass, Posidonia oceanica (L.) Delile, is used in a number of monitoring programs (Calmet et al., 1991; Lopez y Royo et al., 2007; Pergent et al., 2007) and is acknowledged to be a powerful metal bioindicator (Lafabrie et al., 2007; Pergent-Martini \& Pergent, 2000).

Even if trace metals and PAHs are currently used in monitoring programs (Andral et al., 2004), very few studies have been interesting in their correlations and common sources (Alfani et al., 2001; Maisto et al., 2004). The aim of this study is to compare inorganic (trace metal) and organic (PAH) contamination in $P$. oceanica leaves, and to identify the relationship between these types of pollutants, in order to constitute a first step in the identification of contamination sources and fundamental data for ecological restoration and reconstruction design. 


\section{Materials and methods}

21 orthotropic shoots of Posidonia oceanica were collected by scuba diving, at $10 \pm 2 \mathrm{~m}$ depth, in October 2006, in two sites of the north-western Mediterranean Sea. Toulon (France, Fig. 1), in the vicinity of a large city with an industrial and military harbour, present high concentration in trace metals and PAHs (Andral et al., 2004). Calvi (France - Corsica, Fig. 1), a pristine site close to the Fango UNESCO Man And Biosphere Reserve. Corsica present low contamination levels of trace metals (Andral et al., 2004; Lafabrie et al., 2008) and PAHs (Andral et al., 2004).

For each site, collected shoots were divided into 3 replicates on a pool of adult leaves. Only the blades of adult leaves were retained, as it has been previously reported that most trace metals and PAHs accumulate preferentially in these tissues (Lafabrie et al., 2007). Epiphytes and sediments were removed from the blades using a glass slide. Samples were rinsed (ultrapure water), frozen $\left(-20^{\circ} \mathrm{C}\right)$, freeze-dried $\left(>72 \mathrm{~h}\right.$ in Heto ${ }^{\circledR}$ FD4-85 freeze dryer, HetoHolten A/S) and then manually reduced to a coarse powder, for further metal and $\mathrm{PAH}$ analyses.

Mercury: $50 \mathrm{mg}$ of each sample was weighed in a Teflon digestion vessel $\mathrm{CEM}^{\circledR}$ ACV of $100 \mathrm{ml}$ (CEM Corporation, USA). $5 \mathrm{ml}$ of $69 \% \mathrm{HNO}_{3}$ (Normapur 20428.297 Prolabo $^{\circledR}$ ) and $1 \mathrm{ml}$ of $\mathrm{H}_{2} \mathrm{O}_{2} 30 \%$ (Normapur 23619.297 Prolabo ${ }^{\circledR}$ ) were added. The vessels were sealed and placed into the CEM ${ }^{\circledR}$ MARS 5 chamber. The content of each vessel was poured into $25 \mathrm{ml}$ volumetric flasks and diluted to volume with ultrapure water and then transferred to $60 \mathrm{ml}$ polypropylene flasks. Mineralized samples were analysed with a cold vapour atomic absorption spectrometer (CV-AAS - Perkin Elmer ${ }^{\circledR}$ ) equipped with a flow injection system (FIMS 100) and an autosampler (AS-90). A carrier solution of $5 \%(\mathrm{v} / \mathrm{v})$ nitric acid and a reducing solution of $1.1 \%(\mathrm{p} / \mathrm{v})$ tin chloride (23 742.260 Prolabo $^{\circledR}$ ) and $0.5 \%(p / v)$ hydroxylammonium chloride (24 708.235 Prolabo ${ }^{\circledR}$ ) in $3 \%(\mathrm{v} / \mathrm{v})$ hydrochloric acid $\left(20253.293\right.$ Prolabo $^{\circledR}$ ) were used. The standard addition method was applied for calibration. Calibration standards were prepared from a mercury standard solution of $1000 \mathrm{mg}^{-\mathrm{L}^{-1}}$ (30 130.263 Prolabo $^{\circledR}$ ).

Lead and silver: The analyses of these elements were run with quality assurance procedures at the Laboratory of Rouen / ETSA (Rouen, France). They were performed using a graphite furnace atomic absorption spectrometer (GF-AAS).

The analytical procedures were verified using the certified reference material Lagarosiphon major, CRM 60 (Community Bureau of Reference - Commission of the European Communities).

PAH were extracted from $0.5 \mathrm{~g}$ (dry wt.) of Posidonia oceanica leaf powder using an accelerated solvent extractor (ASE 200, Dionex ${ }^{\circledR}$ ). They were reduced and purified on a silica and a alumina spe column. The solution obtained was retaken in $1 \mathrm{ml}$ of acetonitrile (hypergrade, Merk ${ }^{\circledR}$ ). Extracts were analysed by High Performance Liquid Chromatography (HPLC; Dionex ${ }^{\circledR}$ ) together with a fluorescence detector (RF 2000 Fluorescence detector, Dionex ${ }^{\circledR}$ ) and an UV detector (UVD170U, Dionex ${ }^{\circledR}$ ).

Sixteen PAHs were measured: naphthalene (Nap), acenaphtylene (Acy), acenaphthene (Ace), fluorene (Flr), phenanthrene (Phe), anthracene (Ant), fluoranthene (FIt), pyrene (Pyr), benzo(a)anthracene (BaA), chrysene (Chry), benzo(b)fluoranthene $(\mathrm{BbF})$, benzo(k)fluoranthene $(\mathrm{BkF})$, benzo(a)pyrene (BaP), dibenzo(a,h)anthracene (DahA), benzo(g,h,i)perylene (BghiP), indeno(1,2,3-cd)pyrene 
(Ind, PAH-mix9 in acetonitrile Cluzeau ${ }^{\circledR}$ ). Total PAHs was determined by the sum of these PAHs.

The analytical procedure was verified using certified reference material (Fucus sp, IAEA-140/OC) provided by the Analytical Quality Control Service (International Atomic Energy Agency).

In order to determine differences between sites, a Man-Whitney $U$ test was performed on each measured compound. Correlations were determined by Spearman rank test.

\section{Results}

$\mathrm{Ag}, \mathrm{Hg}$ and $\mathrm{Pb}$ concentrations are significantly higher in Toulon than in Calvi (Table I). Toulon presents 1.4 times higher $\mathrm{Ag}$ concentration than Calvi, 3.8 times higher $\mathrm{Hg}$ concentration, and 2.0 times higher $\mathrm{Pb}$ concentration (Table I).

Among the 14 PAHs detected, three of them exhibit significantly higher concentrations in Toulon (Phe $p<0.10$, BghiP $p<0.05$ and Ind $p<0.05$ ) and 9 present maximum values in this site (Table II). Moreover, the sum of Medium Molecular Weight and the sum High Molecular Weight PAHs are significantly higher in Toulon (Man and Whithney $U$ test, respectively $p<0.10$ and $p<0.05$ ).

\section{Discussion and conclusion}

$\mathrm{Hg}$ and $\mathrm{Pb}$ concentrations in Posidonia oceanica blades of Calvi are in same order than those measured along the Corsican coastline (Lafabrie et al., 2008). A study of Florida seagrasses recorded PAH contamination below detection levels in all tissues (Lewis et al., 2007). Whereas, a study on Posidonia oceanica leaves record higher concentration of PAHs (Bucalossi et al., 2006) may be due to sites, studied PAHs and seasonal variation. Toulon higher values are in accordance with a previous study carried out on mussels (Mytilus galoprovincialis), in which this site presented higher metal $(\mathrm{Hg}, \mathrm{Pb})$ and Flt (a MMW PAH) concentrations than Corsican sites (Andral et al., 2004).

$\mathrm{Ag}, \mathrm{Hg}$ and $\mathrm{Pb}$ concentrations in Toulon confirm the anthropic pressure of the site (Andral et al., 2004) and the potential of Posidonia oceanica as a biointegrator of metal contamination (Campanella et al., 2001; Lafabrie et al., 2007; Marin-Guirao et al., 2005; Pergent-Martini \& Pergent, 2000). In the same way, PAHs, and specifically Medium Molecular Weight (MMW) and High Molecular Weight (HMW) PAHs, exhibit higher concentrations in Toulon. Concentrations of MMW and HMW PAHs have been reported as related to human activities (Baumard et al., 1999).

In addition, $\mathrm{Ag}$ and $\mathrm{Pb}$ present a high positive correlation (Table III). These metals are used in pressure evaluations of urban and/or industrial centers (Murray et al., 2004; O'Connor, 1998). Indeed, $\mathrm{Pb}$ is related to atmospheric inputs (UNEP, 2006) and to gasoline (Zhang et al., 2009), and Ag to seawage treatment (Rozan \& Hunter, 2001). The significant presence of these two pollutants is thus linked to the city of Toulon and 
its industrial activities. This is in agreement with a study of Andral et al. (2004) which report more marked contamination in the vicinity of major urban and industrial centers (Golf of Fos, Marseille, Toulon).

Concerning PAHs, BghiP is correlated to Phe and Ind (Table IV); moreover, HMW and MMW PAHs are correlated at 0.90 (spearman $<0.05$ ). Thus, human-induced pressures could be recorded by these types of PAHs.

Several ratios between specific PAHs can be used to determine the origin (petrogenic and/or pyrolytic) of these contaminants (Table V). In the present study, PAHs recorded in Toulon appear to be of petrogenic origine.

Moreover, correlations are observed between the inorganic and organic contaminants. Indeed, significant correlations are observed between (i) BghiP and the three metals, (ii) Ind and $\mathrm{Ag} / \mathrm{Pb}$, and (iii) Phe and $\mathrm{Hg}$ (Tab III). ). Concerning the molecular weight, a significant positive correlation is observed between (i) the three metals and the High Molecular Weight (HMW), and (ii) Hg and Medium Molecular Weight (MMW) (Table VI).

Only few studies focused on the relationship between trace metals and PAHs contamination. In the Quercus ilex L. leaves, the correlation between sum of trace metals ( $\mathrm{Cd}, \mathrm{Ni}, \mathrm{Pb}, \mathrm{V}, \mathrm{Zn}$ ) and sum of PAHs is an evidence of vehicular traffic (Alfani et al., 2001). In terrestrial soil, the positive correlation between sum of $27 \mathrm{PAHs}$ and $\mathrm{Pb}$, $\mathrm{Cu}, \mathrm{Zn}$ suggest a common source: vehicular traffic and its consequent deposition (Maisto et al., 2004). For the first time, a similar correlation is observed in a coastal environment, by using a seagrass bioindicator.

These study underline the ability of the plant to accumulate heavy metals and PAHs from its surrounding environment in its leaves. Death leaves stay in situ or are exported to other ecosystem (Pergent et al., 1994). These results could constitute fundamental data for ecological restoration, reconstruction design or further phytoremediation test.

\section{Acknowledgments}

This study was supported by a grant from the "Collectivité Territoriale de Corse" and by the MONIQUA and GdR Programs, set up within the framework of the INTERREG IIIA Convention. We wish to thank B. Mimault and Ifremer for diving assistance, and C. Lopez y Royo for English correction.

\section{References}

Alfani, A., Maisto, G., Prati, M. V., Baldantoni, D., 2001. Leaves of Quercus ilex L. as biomonitors of PAHs in the air of Naples (Italy). Atmos. Environ. 35, 3553-3559.

Andral, B., Stanisiere, J. Y., Sauzade, D., Damier, E., Thebault, H., Galgani, F., Boissery, P., 2004. Monitoring chemical contamination levels in the Mediterranean based on the use of mussel caging. Mar. Poll. Bull. 49, 704-712. 
Baumard, P., Budzinski, H., Garrigues, P., 1998a. PAHs in Arcachon Bay, France: Origin and biomonitoring with caged organisms. Mar. Poll. Bull. 36, 577-586.

Baumard, P., Budzinski, H., Garrigues, P., Burgeot, T., Michel, X., Bellocq, J., 1999. Polycyclic aromatic hydrocarbon (PAH) burden of mussels (Mytilus sp.) in different marine environments in relation with sediment PAH contamination, and bioavailability. Mar. Environ. Res. 47, 415-439.

Baumard, P., Budzinski, H., Michon, Q., Garrigues, P., Burgeot, T., Bellocq, J., 1998b. Origin and bioavailability of PAHs in the Mediterranean sea from mussel and sediment records. Estuar. Coast. Shelf. S. 47, 77-90.

Baysal, A., Tuncer, S., 1994. Radioactivity Levels in Fish, Shellfish, Algae and Seagrass Collected from the Eastern Black-Sea Coast of Turkey, 1992. Toxicological and Environmental Chemistry 42, 149-153.

Belpomme, D., Irigaray, P., Hardell, L., Clapp, R., Montagnier, L., Epstein, S., Sasco, A. J., 2007. The multitude and diversity of environmental carcinogens. Environ. Res. $105,414-429$.

Benoit, G., Comeau, A., 2005. Méditerranée - les perspectives du plan bleu sur l'environment et le developpement, PNUE.

Bucalossi, D., Leonzio, C., Casini, S., Fossi, M. C., Marsili, L., Ancora, S., Wang, W., Scali, M., 2006. Application of a suite of biomarkers in Posidonia oceanica (L.) delile to assess the ecotoxicological impact on the coastal environment. Mar. Environ. Res. 62, S327-S331.

Calmet, D., Charmasson, S., Gontier, G., Meinesz, A., Boudouresque, C. F., 1991. Chernobyl Radionuclides in the Mediterranean Seagrass Posidonia-Oceanica, 19861987. J. Environ. Radioactiv. 13, 157-173.

Campanella, L., Conti, M. E., Cubadda, F., Sucapane, C., 2001. Trace metals in seagrass, algae and molluscs from an uncontaminated area in the Mediterranean. Environ. Pollut. 111, 117-126.

Doust, L. L., Doust, J. L., Biernacki, M., 1994. American Wild Celery, VallisneriaAmericana, As A Biomonitor of Organic Contaminants in Aquatic Ecosystems. Journal of Great Lakes Research 20, 333-354.

EEA, 2006. Priority issues in the Mediterranean environment, European Environment Agency Report, pp. 1-92.

Goldberg, E. D., 1986. The Mussel Watch Concept. Environ. Monit. Assess. 7, 91-103.

Haynes, D., Muller, J., Carter, S., 2000. Pesticide and herbicide residues in sediments and seagrasses from the Great Barrier Reef world heritage area and Queensland coast. Mar. Poll. Bull. 41, 279-287.

Huesemann, M. H., Hausmann, T. S., Fortman, T. J., Thom, R. M., Cullinan, V., 2009. In situ phytoremediation of PAH- and PCB-contaminated marine sediments with eelgrass (Zostera marina). Ecological Engineering 35, 1395-1404. 
Kantin, R., Pergent, G., 2007. Rapport final, Groupement de Recherche "Gestion des Ecosystèmes Littoraux Méditerranéens". Ifremer Provence Alpes Corse et Université de Corse, pp. 1-189.

Lafabrie, C., Pergent, G., Kantin, R., Pergent-Martini, C., Gonzalez, J. L., 2007. Trace metals assessment in water, sediment, mussel and seagrass species - Validation of the use of Posidonia oceanica as a metal biomonitor. Chemosphere 68, 2033-2039.

Lafabrie, C., Pergent-Martini, C., Pergent, G., 2008. Metal contamination of Posidonia oceanica meadows along the Corsican coastline (Mediterranean). Environ. Pollut. 151, 262-268.

Lin, Q. X., Mendelssohn, I. A., 2009. Potential of restoration and phytoremediation with Juncus roemerianus for diesel-contaminated coastal wetlands. Ecological Engineering $35,85-91$.

Lopez y Royo, C., Pergent, G., Pergent-Martini, C., Casazza, G., 2007. Monitoring Posidonia oceanica in the mediterranean: datawarehousing approach, in: PergentMartini, C., El Asmi, S., La Ravallec, C. (Eds.), RAC/SPA, Tunis,pp. 96-103.

Maisto, G., De Nicola, F., Prati, M. V., Alfani, A., 2004. Leaf and soil PAH accumulation in an urban area of the Mediterranean region (Naples-Italy). Fresen. Environ. Bull. 13, 1263-1268.

Marin-Guirao, L., Atucha, A. M., Barba, J. L., Lopez, E. M., Fernandez, A. J. G., 2005. Effects of mining wastes on a seagrass ecosystem: metal accumulation and bioavailability, seagrass dynamics and associated community structure. Mar. Environ. Res. 60, 317-337.

Murray, K. S., Rogers, D. T., Kaufman, M. M., 2004. Heavy metals in an urban watershed in southeastern Michigan. J. Environ. Qual. 33, 163-172.

NRC, 2003. Oil in the sea III: inputs, fates, and effects, Washington, DC.

O'Connor, T. P., 1998. Mussel Watch results from 1986 to 1996. Mar. Poll. Bull. 37, 1419.

Pergent, G., Pergent-Martini, C., Casalta, B., Lopez y Royo, C., Mimault, B., Salivasdecaux, M., Short, F., 2007. Comparison of three seagrass monitoring systems: seagrassnet, "Posidonia" programme and RSP, in: Pergent-Martini, C., El Asmi, S., La Ravallec, C. (Eds.), RAC/SPA, Tunis,pp. 141-150.

Pergent, G., Romero, J., Pergentmartini, C., Mateo, M. A., Boudouresque, C. F., 1994. Primary Production, Stocks and Fluxes in the Mediterranean Seagrass PosidoniaOceanica. Marine Ecology-Progress Series 106, 139-146.

Pergent-Martini, C., Pergent, G., 2000. Marine phanerogams as a tool in the evaluation of marine trace-metal contamination: an example from the Mediterranean. Int. J. Environ. Pollut. 13, 126-147.

Rozan, T. F., Hunter, K. S., 2001. Effects of discharge on silver loading and transport in the Quinnipiac River, Connecticut. Sci. Total Environ. 279, 195-205. 
Short, F. T., Coles, R. G., Pergent-Martini, C., 2001. Global seagrass distribution, Global Seagrass Research Methods. Short, F. T., Coles, R. G. (Eds.), Amsterdam, pp. 5-30.

Stella, A., Piccardo, M. T., Coradeghini, R., Redaelli, A., Lanteri, S., Armanino, C., Valerio, F., 2002. Principal component analysis application in polycyclic aromatic hydrocarbons "mussel watch" analyses for source identification. Anal. Chim. Acta 461, 201-213.

UNEP, 2006. Interim review of scientific information on lead, DTIE/CHEMICALS. pp. 1191.

Usero, J., Morillo, J., Gracia, I., 2005. Heavy metal concentrations in molluscs from the Atlantic coast of southern Spain. Chemosphere 59, 1175-1181.

Warnau, M., Fowler, S. W., Teyssie, J. L., 1996. Biokinetics of selected heavy metals and radionuclides in two marine macrophytes: The seagrass Posidonia oceanica and the alga Caulerpa taxifolia. Mar. Environ. Res. 41, 343-362.

White, J. C., Mattina, M. J. I., Eitzer, B. D., lannucci-Berger, W., 2002. Tracking chlordane compositional and chiral profiles in soil and vegetation. Chemosphere 47, 639-646.

Zhang, M. Y., Cui, L. J., Sheng, L. X., Wang, Y. F., 2009. Distribution and enrichment of heavy metals among sediments, water body and plants in Hengshuihu Wetland of Northern China. Ecological Engineering 35, 563-569.

\section{Tables}

Table 1. Trace metal concentrations (mean \pm S.E.; in $\mu g . g^{-1}$ dry wt.; ${ }^{* *}$ : $p<0.05$ ).

\begin{tabular}{lrlrl}
\hline & \multicolumn{2}{c}{ Toulon } & \multicolumn{2}{c}{ Calvi } \\
\hline $\mathrm{Ag}^{* *}$ & $\mathbf{0 . 7}$ & $\pm \mathbf{0 . 0}$ & 0.5 & \pm 0.0 \\
$\mathrm{Hg}^{* *}$ & $\mathbf{0 . 1 5}$ & $\pm \mathbf{0 . 0 3}$ & $0.04 \quad \pm 0.01$ \\
$\mathrm{~Pb}^{* *}$ & $\mathbf{3 . 0} \pm \mathbf{0 . 1}$ & $1.5 \pm 0.3$ \\
\hline
\end{tabular}


Table 2. PAHs concentrations (mean \pm S.E.; in $\mu g . \mathrm{kg}^{-1}$ dry wt.; -: bellow detection level; $\left.{ }^{* *} p<0.05,{ }^{*} p<0.10\right)$

\begin{tabular}{|c|c|c|c|c|c|c|}
\hline & \multicolumn{3}{|c|}{ Toulon } & \multicolumn{3}{|c|}{ Calvi } \\
\hline \multicolumn{7}{|c|}{ Low Molecular Weight } \\
\hline Nap & & - . & & & - . & \\
\hline Acy & & - . & & & - . & \\
\hline Ace & 4.4 & \pm & 0.6 & 5.2 & \pm & 1.1 \\
\hline FIr & 19.3 & \pm & 1.9 & 20.8 & \pm & 5.7 \\
\hline \multicolumn{7}{|c|}{ Medium Molecular Weight } \\
\hline $\mathrm{Phe}^{*}$ & 84.6 & \pm & 13.0 & 53.2 & \pm & 6.6 \\
\hline Ant & 2.3 & \pm & 0.3 & 2.7 & \pm & 0.5 \\
\hline Flt & 18.7 & \pm & 1.6 & 15.8 & \pm & 2.7 \\
\hline Pyr & 18.6 & \pm & 1.0 & 15.0 & \pm & 3.0 \\
\hline $\mathrm{BaA}$ & 22.8 & \pm & 1.2 & 20.1 & \pm & 2.0 \\
\hline Chry & 12.0 & \pm & 1.1 & 11.7 & \pm & 2.5 \\
\hline \multicolumn{7}{|c|}{ High Molecular weight } \\
\hline $\mathrm{BbF}$ & 23.4 & \pm & 1.8 & 19.3 & \pm & 4.1 \\
\hline $\mathrm{BkF}$ & 3.0 & \pm & 0.6 & 1.9 & \pm & 0.4 \\
\hline $\mathrm{BaP}$ & 3.3 & \pm & 0.1 & 2.2 & \pm & 0.6 \\
\hline DahA & 1.4 & \pm & 0.1 & 1.1 & \pm & 0.3 \\
\hline BghiP $^{* *}$ & 4.9 & \pm & 0.2 & 0.8 & \pm & 0.3 \\
\hline $\operatorname{lnd}^{* *}$ & 8.9 & \pm & 0.4 & 0.7 & \pm & 0.2 \\
\hline
\end{tabular}

Table 3. Spearman correlation coefficient between metals $\left({ }^{* *} p<0.05,{ }^{*} p<0.10\right)$

\begin{tabular}{llll}
\hline & $\mathrm{Ag}$ & $\mathrm{Hg}$ & $\mathrm{Pb}$ \\
\hline $\mathrm{Ag}$ & 1.00 & & \\
$\mathrm{Hg}$ & 0.62 & 1.00 & \\
$\mathrm{~Pb}$ & $0.90^{* *}$ & 0.64 & 1.00 \\
\hline
\end{tabular}


Table 4. Spearman correlation coefficient between significant PAHs $\quad\left({ }^{* *} p<0.05\right.$, $\left.{ }^{*} \mathrm{p}<0.10\right)$

\begin{tabular}{clll}
\hline & Phe & BghiP & Ind \\
\hline Phe & 1.00 & & \\
BghiP & $0.87^{*}$ & 1.00 & \\
Ind & 0.70 & $0.75^{*}$ & 1.00 \\
\hline
\end{tabular}

Table 5. Determination of contamination origin by the application of bibliographic ratios on Posidonia oceanica results (bold: more petrogenic site, ${ }^{* *} p<0.05,{ }^{*} p<0.10$ ).

\begin{tabular}{|c|c|c|c|c|c|c|c|c|c|}
\hline \multirow[b]{2}{*}{ Ratios } & \multicolumn{6}{|c|}{ Posidonia results } & \multicolumn{2}{|c|}{ Origin } & \multirow[t]{2}{*}{ Authors } \\
\hline & \multicolumn{3}{|c|}{ Toulon } & \multicolumn{3}{|c|}{ Calvi } & $\begin{array}{l}\text { Petrogeni } \\
\quad \mathrm{C}\end{array}$ & Pyrolytic & \\
\hline Phe/Ant* & 37.05 & \pm & 2.57 & 23.69 & \pm & 1.15 & $>15$ & $<10$ & $\begin{array}{c}\text { Baumard et al., } \\
\text { 1998b; Stella et al., } \\
2002\end{array}$ \\
\hline Chry/BaA & 0.53 & \pm & 0.04 & 0.57 & \pm & 0.06 & $>1$ & $<1$ & $\begin{array}{l}\text { Baumard et al., 1999; } \\
\text { Stella et al., } 2002\end{array}$ \\
\hline Flt/Pyr & 1.00 & \pm & 0.03 & 1.06 & \pm & 0.07 & $<1$ & $>1$ & Baumard et al., 1998b \\
\hline BaP/BghiP** & 0.67 & \pm & 0.02 & 3.03 & \pm & 0.66 & Low & High & Stella et al., 2002 \\
\hline
\end{tabular}

Table 6. correlation between metals and PAHs $\left({ }^{* *} p<0.05,{ }^{*} p<0.10\right)$

\begin{tabular}{llll}
\hline & $\mathrm{Ag}$ & $\mathrm{Hg}$ & $\mathrm{Pb}$ \\
\hline Phe & 0.67 & $0.90^{* *}$ & 0.67 \\
$\begin{array}{l}\text { BghiP } \\
\text { Ind }\end{array}$ & $0.76^{*}$ & $0.84^{* *}$ & $0.88^{* *}$ \\
& $0.97^{* *}$ & 0.66 & $0.81^{* *}$ \\
Sum & 0.67 & $0.90^{* *}$ & 0.67 \\
& & & \\
LMW & 0.09 & 0.31 & 0.46 \\
MMW & 0.67 & $0.90^{* *}$ & 0.67 \\
HMW & $0.79^{*}$ & $0.77^{*}$ & $0.90^{* *}$ \\
\hline
\end{tabular}


Figures

Figure 1. Sampling sites (represented by stars) in the North-western Mediterranean sea.

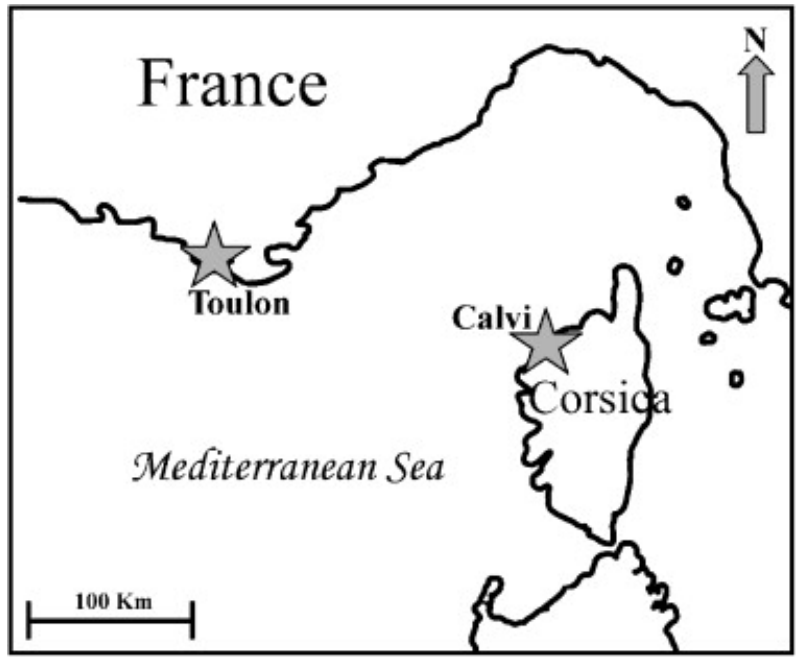

